\title{
Verapamil inhibits tumor progression of chemotherapy- resistant pancreatic cancer side population cells
}

\author{
LU ZHAO ${ }^{1-3^{*}}$, YUE ZHAO ${ }^{1,3^{*}}$, BETTINA SCHWARZ $^{3,4}$, JOSEF MYSLIWIETZ ${ }^{5}$, ROLAND HARTIG ${ }^{6}$, \\ PETER CAMAJ $^{1,3}$, QI BAO ${ }^{3,7}$, KARL-WALTER JAUCH ${ }^{3}$, MAKUS GUBA $^{3}$, JOACHIM WALTER ELLWART $^{5}$, \\ PETER JON NELSON ${ }^{8}$ and CHRISTIANE JOSEPHINE BRUNS ${ }^{1,3}$ \\ ${ }^{1}$ Department of Surgery, Otto-von-Guericke University, Magdeburg, Germany; ${ }^{2}$ Thyroid and Breast Surgery Department, \\ Tongji Hospital, Tongji Medical College, Huazhong University of Science and Technology, Wuhan, Hubei, P.R. China; \\ ${ }^{3}$ Department of Surgery, Munich Medical Center, Campus Grosshadern, LMU, Munich; ${ }^{4}$ Department of Anaesthesia, \\ University Hospital Heidelberg; ${ }^{5}$ Institute of Molecular Immunology, Helmholtz Center for Environment and Health, \\ Munich; ${ }^{6}$ Institute of Molecular and Clinical Immunology, Otto-von-Guericke University, Magdeburg, Germany; \\ ${ }^{7}$ Department of Plastic and Reconstructive Surgery, 2nd Affiliated Hospital, School of Medicine, \\ Zhejiang University, Hangzhou, Zhejiang, P.R. China; ${ }^{8}$ Clinical Biochemistry Group, \\ Medical Clinic and Policlinic IV, Munich Medical Center, Campus Innenstadt, LMU, Munich, Germany
}

Received January 14, 2016; Accepted March 28, 2016

DOI: $10.3892 /$ ijo.2016.3512

\begin{abstract}
Tumor side population (SP) cells display stemlike properties that can be modulated by treatment with the calcium channel blocker verapamil. Verapamil can enhance the cytotoxic effects of chemotherapeutic drugs and multidrug resistance by targeting the transport function of the P-glycoprotein (P-gp). This study focused on the therapeutic potential of verapamil on stem-like SP tumor cells, and further investigated its chemosensitizing effects using L3.6pl and AsPC-1 pancreatic carcinoma models. As compared to parental L3.6pl cells $(0.9 \pm 0.22 \%)$, L3.6pl gemcitabine-resistant cells $\left(\mathrm{L} 3.6 \mathrm{pl}_{\mathrm{Gres}}\right)$ showed a significantly higher percentage of SP cells $(5.38 \pm 0.99 \%)$ as detected by Hoechst 33342/FACS assays. The L $3.6 \mathrm{pl}_{\text {Gres }} \mathrm{SP}$ cells showed stable gemcitabine resistance, enhanced colony formation ability and increased
\end{abstract}

Correspondence to: Dr Yue Zhao or Professor Christiane J. Bruns, Department of Surgery, Otto-von-Guericke University, Leipziger Strasse 40-H60a, D-39120 Magdeburg, Germany

E-mail: yue.zhao@med.ovgu.de

E-mail: christiane.bruns@med.ovgu.de

${ }^{*}$ Contributed equally

Abbreviations: ABC, ATP-binding cassette; CSCs, cancer stem cells; CNT, concentrative nucleoside transporter; ENT, equilibrative nucleoside transporter; EMT, epithelial-to-mesenchymal transition; GSH, glutathione; H33342, Hoechst 33342; HSC, hematopoietic stem cells; MDR, multidrug resistance; MRP, multidrug resistanceassociated protein; PKC, protein kinase C; P-gp, P-glycoprotein; SP, side population

Key words: gemcitabine, P-glycoprotein, side population, verapamil tumorigenicity. Verapamil effectively inhibited L3.6 $\mathrm{pl}_{\text {Gres }}$ and AsPC-1 SP cell proliferation in vitro. A pro-apoptotic effect of verapamil was observed in $\mathrm{L} 3.6 \mathrm{pl}$ cells, but not in $\mathrm{L}^{3} .6 \mathrm{pl}_{\text {Gres }}$ cells, which was linked to their differential expression of P-gp and equilibrative nucleoside transporter-1 (ENT-1). In an orthotopic pancreatic cancer mouse model, both low and high dose verapamil was shown to substantially reduce $\mathrm{L} 3.6 \mathrm{pl}_{\mathrm{Gres}}-\mathrm{SP}$ cell tumor growth and metastasis, enhance tumor apoptosis, and reduce microvascular density.

\section{Introduction}

Pancreatic cancer is the fourth or fifth most common cause of cancer-related death in most western industrialized countries. The disease has a poor prognosis with a 5-year survival rate of $<5 \%$. In unresectable cases, chemo- or radiotherapy is used for palliation of symptoms and improvement of survival $(1,2)$. Gemcitabine is currently the standard systemic treatment for unresectable and advanced pancreatic cancer, which can extend patient survival by 5-6 months (3). To date, a more satisfactory outcome has not been reported when gemcitabine is used in combination with other cytotoxic drugs (3-5).

The molecular basis for the resistance of pancreatic cancers to chemotherapy is not fully understood. It appears to result from various mechanisms that can each influence tumor resistance to gemcitabine. One form of drug resistance, termed multidrug resistance (MDR), is linked to the expression of proteins that act as drug efflux pumps. MDR is characterized by the development of broad cross-resistance to functionally and structurally unrelated drugs. This enhanced efflux of drugs is mediated by a super family of membrane glycoproteins, the ATP-binding cassette (ABC) transporters. The ABCB superfamily includes a $170-\mathrm{kDa}$ transporter protein (ABCB1), also termed P-glycoprotein (P-gp). P-gp is comprised of the protein product of the human MDR1 
gene in complex with the multidrug resistance-associated protein (MRP) (6). The expression of P-gp correlates with both the decreased accumulation of drugs, and the degree of chemoresistance in many different human cancer cells (7-9). Generally, $40-50 \%$ of patient tumors exhibit overexpression of P-gp (10). Although gemcitabine is a substrate for the ATP-dependent efflux pump (11), it is predominantly transported into the cell via facilitated diffusion mediated by the equilibrative nucleoside transporter (ENT), and sodiumdependent transporters (concentrative nucleoside transporter, CNT) $(12,13)$. Pancreatic tumor cells can express high levels of ENT1, whereas members of the CNT family are present at only negligible levels (14).

Emerging evidence suggests that cancer stem cells (CSCs), a small subset of undifferentiated cells found within tumors, play a key role in tumorigenicity and malignancy (15). SP cells represent a small subpopulation of tumor cells that have properties associated with CSC in that they can rapidly efflux lipophilic fluorescent dyes producing a characteristic profile in fluorescence-activated flow cytometric analysis (16). SP cells are generally defined by their ability to efflux the fluorescent DNA binding dye Hoechst 33342 (H33342) and the differential emission spectra of this dye when it binds chromatin (16). The pumps responsible for dye efflux are attributed to the $\mathrm{ABC}$ superfamily transporters, including the MDR1/P-glycoprotein, ABCG2, MRP1 and ABCA2 (17-20). These pumps also transport chemotoxic drugs out of the cell, including vinblastine, doxorubicin, daunorubicin and paclitaxel (21). SP cells exhibit increased chemoresistance following in vitro exposure to gemcitabine $(22,23)$. The FACS-based assay used to detect the presence of side populations is also currently under evaluation as a general method to identify and isolate CSCs subpopulations within tumor samples.

Verapamil is a calcium channel blocker that is utilized clinically to treat cardiac arrhythmias (24). It is also a first generation inhibitor of P-gp (25). When combined with chemotherapeutic agents, verapamil can help to promote intracellular drug accumulation (26). This has been demonstrated in non-small cell lung cancer, colorectal carcinoma, leukemia, and neuroblastoma cell lines (27-30). Based on this ability of verapamil to inhibit P-gp transport activity, it can also be used as an 'SP' blocker in the Hoechst 33342 assay as it will substantially reduce SP cells as visualized by flow cytometry analysis. Based on these observations, we hypothesized that verapamil treatment may directly exert anti-SP effects and therefore enhanced gemcitabine sensitivity in pancreatic cancer.

In this study, the biological characteristics of CSCs in pancreatic cancer SP cells including their self-renewal ability, resistance to gemcitabine, and general tumorigenicity were investigated in the context of verapamil treatment.

\section{Materials and methods}

Human pancreatic cancer cells and culture conditions. Human pancreatic adenocarcinoma cell lines L3.6pl (31) and AsPC-1 (American Tissue Culture Collection) were maintained in Dulbecco's minimal essential medium (D-MEM; Invitrogen $\mathrm{GmbH}$, Karlsruhe, Germany), supplemented with $10 \%$ fetal bovine serum (Biochrom AG, Berlin, Germany), 2\% MEM vitamin mixture (PAN Biotech GmbH, Aidenbach, Germany), $2 \%$ MEM NEAA (PAN Biotech GmbH), $1 \%$ penicillin streptomycin (PAN Biotech $\mathrm{GmbH}$, Aidenbach, Germany) and $2 \%$ glutamax (Invitrogen $\mathrm{GmbH}$ ). Cells were incubated in a humidified incubator $\left(37^{\circ} \mathrm{C}, 5 \% \mathrm{CO}_{2}\right)$, grown in cell culture flasks, and passaged on reaching $70-80 \%$ confluence.

A gemcitabine-resistant pancreatic cancer cell line, termed L3.6pl $\mathrm{pres}_{\text {Gre }}$, was developed from the parental L3.6pl cell line by gradually increasing the concentration of gemcitabine (Gemzar; Lilly Deutschland GmbH, Giessen, Germany) in the cultured cells. Gemcitabine was first added at a concentration of $0.5 \mathrm{ng} / \mathrm{ml}$ (based on the $\mathrm{IC}_{50}$ value of $\mathrm{L} 3.6 \mathrm{pl}$ ). When the cells reached exponential growth, they were subcultured for two additional passages with $0.5 \mathrm{ng} / \mathrm{ml}$ gemcitabine or until the cells grew stably. The concentration of gemcitabine was then increased to $100 \mathrm{ng} / \mathrm{ml}$ and the cells were passaged until a stable gemcitabine-resistant pancreatic cancer cell line $\left(\mathrm{L} 3.6 \mathrm{pl}_{\mathrm{Gres}}\right)$ was established.

Isolation of SP- and non-SP-cell fractions from $L 3.6 p l_{\text {Gres }}$ and AsPC-1 cell lines. SP- and non-SP-cell fractions were identified and isolated using a modified protocol described by Goodell et al (16). Briefly, 1x10\% $/ \mathrm{ml}$ cells were re-suspended in D-MEM containing 2\% fetal bovine serum and labeled with $\mathrm{H} 33342$ (Sigma-Aldrich GmbH, Steinheim, Germany) at a concentration of $2.5 \mu \mathrm{g} / \mathrm{ml}$ for $60 \mathrm{~min}$ in $37^{\circ} \mathrm{C}$ water bath, either alone or with $225 \mu \mathrm{M}$ verapamil hydrochloride (SigmaAldrich $\mathrm{GmbH}$ ). After $60 \mathrm{~min}$ the cells were centrifuged $\left(300 \mathrm{~g}, 4^{\circ} \mathrm{C}\right)$ for $5 \mathrm{~min}$, and then resuspended in ice-cold PBS containing $2 \%$ fetal bovine serum. The cells were passed through a $40-\mu \mathrm{m}$ mesh filter and maintained at $4^{\circ} \mathrm{C}$ in the dark until flow cytometry analysis or sorting. Cells were counterstained with $10 \mu \mathrm{g} / \mathrm{ml}$ propidium iodide to label dead cells, and the entire preparation was then analyzed using a BD-LSRII flow cytometer (BD Biosciences, Heidelberg, Germany) and FlowJo software (Treestar Inc., Ashland, OR, USA), or sorted using a MoFlo cell sorter with the Summit 4.3 software (Beckmann Coulter GmbH, Krefeld, Germany). Hoechst dye was excited at $355 \mathrm{~nm}$ (32), and fluorescence was measured at two wavelengths using a 450/50-nm (blue) band-pass filter and a 670/30-nm (33) long-pass edge filter. Following isolation the SP and non-SP cell fractions were used for in vitro and in vivo assays.

Cell viability and proliferation assay. Trypan blue (SigmaAldrich) staining was used to test for cell viability. The dye stains dead cells, and livings are distinguished by their ability to exclude the dye performing phase contrast microscopy. Cell viability was calculated using the following formula: Cell viability $=$ unstained cells $/$ unstained + trypan blue stained cells $x 100 \%$. Cell proliferation was measured using the Cell Counting Kit-8 (Dojindo Laboratories, Kumamoto, Japan) according to the manufacturer's instructions. In this assay $5,000-8,000$ cells/well were plated in a 96-well plate and grown overnight, and then treated for $24 \mathrm{~h}$ with gemcitabine or verapamil. Cell proliferation was then determined using a VersaMax tunable microplate reader and Softmaxpro 5.2 software for data analysis (Molecular Devices, Sunnyvale, CA, USA). 
Apoptosis assay. Cell apoptosis was analyzed using an Annexin V-FITC assay (Miltenyi Biotec GmbH, Bergisch Gladbach, Germany) according to the manufacturer's instructions. After determination of cell numbers, $1 \times 10^{6}$ cells were washed with binding buffer and centrifuged. The cell pellet was resuspended in binding buffer, and $10 \mu \mathrm{l}$ of Annexin V-FITC per $10^{6}$ cells was added, mixed, and the preparation was incubated for $15 \mathrm{~min}$ in the dark at room temperature. The cells were then washed, and the cell pellet resuspended in binding buffer. The PI solution was added immediately prior to analysis using a BD-LSRII flow cytometer (BD Biosciences, Heidelberg, Germany) and FlowJo software version 7.6 (Treestar Inc.). Experiments were repeated at least three times.

Colony formation assay. To determine the ability of cells to form colonies, 500 cells in $2 \mathrm{ml}$ of D-MEM medium were seeded into each well of a 6 -well plate. The medium was changed two times per week and the assay was stopped when colonies were clearly visible without using a microscope (i.e., each single colony comprised approximately $\geq 50$ cells). The resulting colonies were stained with $0.1 \%$ crystal violet and counted.

Flow cytometry analysis. For this staining procedure, the cells were incubated in the dark and on ice. Firstly they were blocked with PBS containing $0.5 \%$ albumin bovine (BSA) and $0.02 \% \mathrm{NaN}_{3}$ with FCR blocking reagent (Miltenyi Biotec) for $15 \mathrm{~min}$. Cells were then stained with the P-glycoprotein mouse mAb primary antibody (clone C219, Calbiochem, Darmstadt, Germany) for 45 min on ice. Afterwards they were incubated with the fluorescence-conjugated secondary antibody, goat anti-mouse IgG FITC (Abcam, Cambridge, UK) for $45 \mathrm{~min}$. FITC isotype mouse immunoglobulins were used as negative controls. FITC was excited using a 488-nm laser and detected by a 530/30 band-pass filters. Dead cells were excluded by gating on forward and side scatter and eliminating PI-positive population cells. All the data were analyzed using FlowJo software version 7.6 (Treestar Inc.).

Western blot assay. The proteins ENT1 and P-gp were assayed by immunoblotting. Cells were resuspended in ice-cold RIPA buffer supplemented with a cocktail of protease/phosphatase inhibitors (Roche, Mannheim, Germany). Cells were further incubated on ice for $10 \mathrm{~min}$ and centrifuged at 14,000 $\mathrm{g}$ at $4^{\circ} \mathrm{C}$ for $10 \mathrm{~min}$. After determination of the protein concentration using the BCA protein assay (Thermo Fisher Scientific, Rockford, IL, USA), an equal amount of protein was run on polyacrylamide gels and transferred semidry to polyvinylidene difluoride membranes (Amersham, Braunschweig, Germany). The corresponding primary antibody was incubated at $4^{\circ} \mathrm{C}$ overnight. After blocking for $2 \mathrm{~h}$, the secondary antibody was added and incubated for $2 \mathrm{~h}$ at room temperature, following by washing. An enhanced chemiluminescense system(Amersham) was used for detection. Afterwards the membranes were reused for $\beta$-actin staining (Sigma-Aldrich $\mathrm{GmbH}$ ) to ensure equal protein levels. The polyclonal goat anti-mouse/rabbit immunoglobulin HRP (Dako, Glostrup, Denmark) was used according to the manufacturer's instructions. For detection of the ENT1 protein, the anti-ENT1 antibody (Abcam) was used at 1:500 in 5\% BSA-TBST buffer. For P-gp protein detection, the monoclonal mouse C219 antibody (Calbiochem) was used at 1:100 dilutions in $7.5 \%$ skim dried milk-PBST buffer. This antibody recognizes the two P-gp isoforms (34).

Orthotopic pancreatic cancer mouse model. Approval by the animal rights commission of the state of Bavaria, Germany was obtained for all animal experiments. Male athymic Balb/c $\mathrm{nu} / \mathrm{nu}$ mice were purchased from Charles River, Inc. (Sulzfeld, Germany). Mice aged 6-8 weeks with an average weight of $20 \mathrm{~g}$ were maintained under a 12:12-h light-dark cycle and were used for the orthotopic pancreatic cancer mouse model. They were anesthetized using ketamine $[100 \mathrm{mg} / \mathrm{kg}$ body weight (BW), xylazine (5 mg/kg BW] and atropine. The operation was carried out in a sterile manner. A 1-cm left abdominal flank incision was made, the spleen was exteriorized and $1 \times 10^{5}$ isolated SP- and non-SP L3.6pl $\mathrm{pres}_{\text {Gre }}$ cells were injected into the subcapsular region of the pancreas. Before injection, cell viability was assessed by trypan blue staining and only cell preparations that showed $\geq 95 \%$ viability were used for injection. Mice were divided into an SP control group, non-SP control group and different drug treatment SP-groups. Four weeks after orthotopic implantation, therapy was initiated. One treatment group obtained daily (every workday) intraperitoneal injection of low concentration of verapamil $(200 \mu \mathrm{M}$, $0.5 \mathrm{mg} / \mathrm{Kg} \mathrm{BW})$, the second treatment group received a higher concentration of verapamil (10 mM, $25 \mathrm{mg} / \mathrm{Kg} \mathrm{BW})$. Nine weeks after the injection of tumor cells, all the mice were sacrificed and examined for orthotopic tumor growth and development of metastases. The pancreatic tumors as well as other organs were isolated, weighed, and then used for $\mathrm{H} \& \mathrm{E}$ and immunohistochemical staining.

Immunohistochemistry. Formaldehyde-fixed and paraffinembedded tissues were serially sectioned at $3 \mu \mathrm{m}$ and allowed to dry overnight. Sections were deparaffinized in xylene followed by a graded series of ethanol (100, 95 and 80\%) and rehydrated in phosphate-buffered solution, $\mathrm{pH}$ 7.5. Paraffinembedded tissues were used for the Ki67 proliferation index assay, microvascular density analysis, and the TUNEL assay. TUNEL assay was carried out using an in situ cell death detection kit, Fluorescein (Roche Diagnostics GmbH, Mannheim, Germany), according to the manufacturer's instructions. The antibodies used for paraffin-embedded tissues were monoclonal rabbit anti-Ki67 antibody (ab 16667, Abcam) and polyclonal rabbit anti-CD31 (ab 28364, Abcam). The primary antibodies were diluted in PBS containing 3\% bovine serum albumin (BSA). The sample slides were treated for 20 min with blocking solution (8\% goat serum or rabbit serum in PBS with $3 \%$ BSA) before the primary antibody was applied. Endogenous peroxidase was blocked by incubation with $3 \%$ hydrogen peroxide $\left(\mathrm{H}_{2} \mathrm{O}_{2}\right)$. Endogenous avidin and biotin were blocked using the Avidin/Biotin Blocking kit (Vector, USA).

Overnight incubation with the primary antibodies was followed by incubation with the respective biotinylated secondary antibodies (goat anti-rabbit, BA-1000, Vector), followed by the $\mathrm{ABC}$ reagent for signal amplification (Vectastain ABC-Peroxidase kits, PK-4000, Vector). Between the incubation steps, the slides were washed in TBS. 3,3'-diaminobenzidine (DAB, Dako, USA) was used to develop the color. 

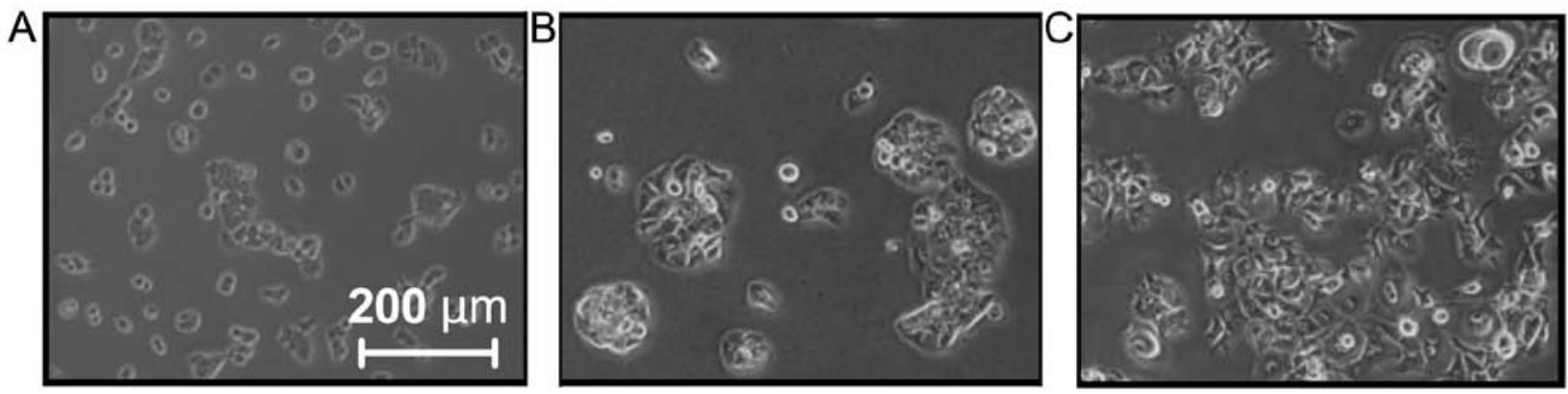

Figure 1. Microscopic images of $\mathrm{L} 3.6 \mathrm{pl}$ and $\mathrm{L} 3.6 \mathrm{pl}_{\text {Gres }}$ following gemcitabine treatment. (A) L3.6pl cells: small and round cells with some irregular relatively larger cells. (B) L3.6pl $\mathrm{Gres}_{\text {Ges }}$ cells after treatment with gemcitabine over 30 days: showing enlarged cell shape. (C) L3.6pl $\mathrm{Gres}_{\text {Ges }}$ cells after treatment with gemcitabine over 60 days: the majority of $\mathrm{L} 3.6 \mathrm{pl}_{\text {Gres }}$ cells have changed their morphology into a fibroblastoid type with loss of polarity, increased intercellular separation and pseudopodia, with a minority of small round cells interspersed.
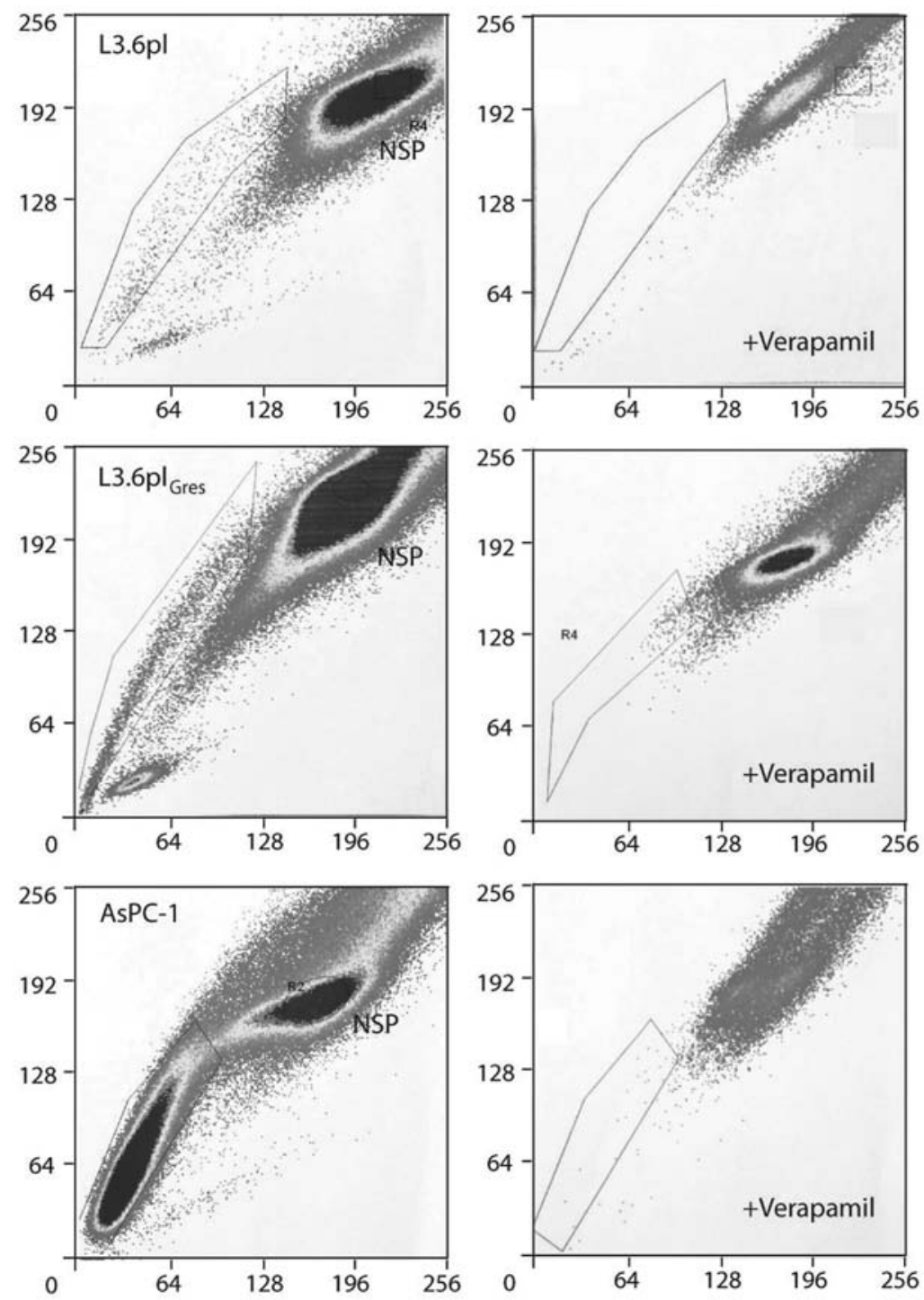

Figure 2. Side population detection. FACS analysis showing proportion of SP cells in L3.6pl $(0.9 \pm 0.22 \%)$ as compared to L3.6pl $\mathrm{Gres}_{\text {res }}$ cells $(5.38 \pm 0.99 \%)$. Using verapamil, the percentage of SP-cells was significantly reduced to $0.16 \pm 0.11 \%$ ( $\mathrm{L} 3.6 \mathrm{pl}$ versus $\mathrm{L} 3.6 \mathrm{pl}+$ verapamil, $\left.\mathrm{p}<5 \mathrm{E}^{-10}\right)$. More SP cells $(21.35 \pm 3.48 \%)$ were identified in the AsPC-1 cell line. Verapamil induced a significant reduction of SP cells to $3.56 \pm 0.87 \%$ (AsPC-1 versus AsPC-1 + verapamil, $\mathrm{p}<5 \mathrm{E}^{-10}$ ). Data are presented as mean \pm standard deviation.

Slides were counter-stained with hematoxylin, mounted in Kaisers Glycerinegelatine (Merck, Germany), and covered.
For quantification of the staining intensity, each index (Ki67, microvascular density CD31, and TUNEL) was evalu- 
A

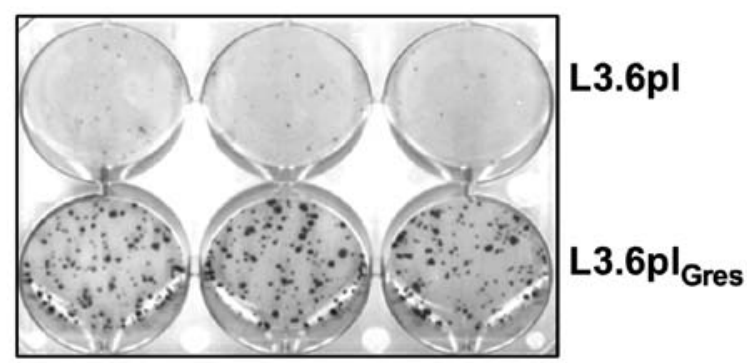

B

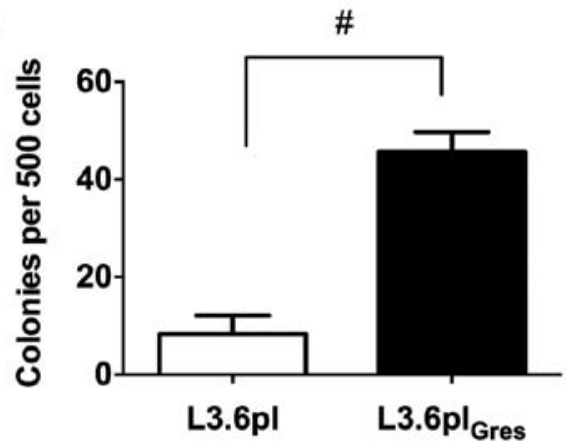

C

D

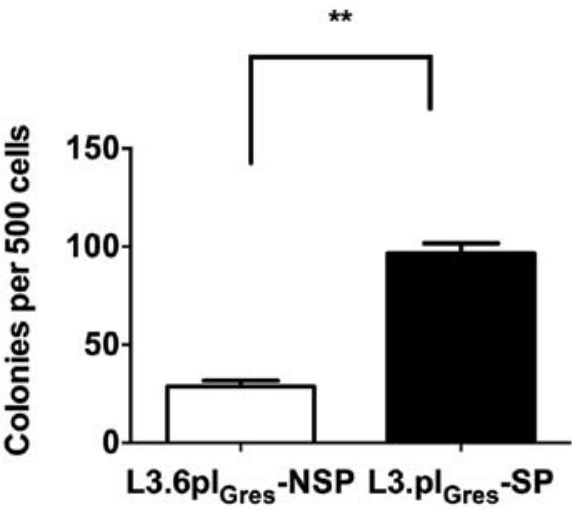

Figure 3. Chemo-resistant SP cells exhibit stronger colony formation ability. SP-enriched L3.6pl $\mathrm{Gres}_{\text {cells }}$ are able to generate more colonies than L3.6pl. (A) The upper three wells were seeded with L3.6pl cells while the lower three wells were seeded with L3.6 $\mathrm{pl}_{\text {Gres }}$ cells. There were many more visible colonies in

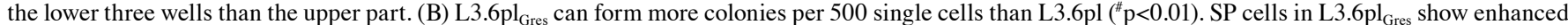
colony formation ability relative to NSP cells. (C) The upper three wells were seeded with L3.6pl $\mathrm{Gres}_{-\mathrm{NSP}}$ cells, while the lower three wells were seeded with L3.6pl $\mathrm{Gres}_{\mathrm{G}} \mathrm{SP}$ cells. There were many more visible colonies in L3.6pl $\mathrm{Gres}_{-\mathrm{SP}}$ than the L3.6pl $\mathrm{Gres}-\mathrm{NSP}$ cells. (D) L3.6pl $\mathrm{Gres}-\mathrm{SP}$ can form more colonies per 500 single cells than L3.6pl $\mathrm{Gres}-\mathrm{NSP}\left({ }^{* *} \mathrm{p}<0.0001\right)$.

ated in a blinded manner. Slides were observed under a high/ low magnification scope (x200/x100), each one was evaluated within 3 fields, and the data were analyzed as mean positive signal (Ki67-positive cells, amount of microvessels, cells with strong FITC-fluorescence) of 3 fields.

Statistical analysis. Statistical evaluation was performed using the paired Student's t-test or ANOVA test(MicrocalOrigin) with $\mathrm{p}<0.05$ considered to be statistically significant $\left[\mathrm{p}<0.05\left({ }^{\&}\right)\right.$; $\mathrm{p}<0.01\left(^{\#)} \mathrm{p}<0.001\left(^{*}\right) ; \mathrm{p}<0.0001\left({ }^{* *}\right)\right]$. GraphPad Prism ${ }^{\circledR} 5.0$ or Microsoft excel 2010 software were used to generate graphs and tables.

\section{Results}

Side population cells are enriched in L3.6pl $\mathrm{pres}_{\text {cells and }}$ show higher colony formation. The human pancreatic adenocarcinoma cell line L3.6pl was continuously cultured with gemcitabine, starting at $0.5 \mathrm{ng} / \mathrm{ml}$, which was then gradually increased to $100 \mathrm{ng} / \mathrm{ml}$ over multiple cell passages to eventually develop a gemcitabine-resistant version of the cell line ( $\left.\mathrm{L} 3.6 \mathrm{pl}_{\text {Gres }}\right)$. The $24 \mathrm{~h} \mathrm{IC} \mathrm{IC}_{50}$ increased from $6.1 \pm 0.9 \mathrm{ng} / \mathrm{ml}$ in the parental L3.6pl cells, to $498.8 \pm 3.2 \mathrm{ng} / \mathrm{ml}$ in the $\mathrm{L} 3.6 \mathrm{pl}_{\mathrm{Gres}}$ cells (L3.6pl vs. $\mathrm{L}^{2} .6 \mathrm{pl}_{\text {Gres }} \mathrm{p}<1 \mathrm{E}^{-9}$ ). The general morphology of $\mathrm{L} 3.6 \mathrm{pl}_{\text {Gres }}$ cells was also changed with gemcitabine resistance into large fibroblastoid-like tumor cells (Fig. 1), while the parental L3.6pl cell line maintained its original round shape. By contrast, the AsPC-1 line, which was largely resistant to gemcitabine and presented with a spindle-like shape, did not show a change in morphology under gemcitabine selection (data not shown).

The L3.6pl and AsPC-1 cell lines were assayed for the presence of SP-cells. Verapamil hydrochloride, which blocks transporters of the ABC family and abrogates the ability of cells to efflux the dye, served as an SP cell control in the H33342 assay (SP cells will disappear or decrease in the presence of ABCG2 inhibitors owing to inhibition of Hoechst efflux from the cells). Both cell lines were found to contain a distinct proportion of SP cells. The percentage of SP cells increased from $0.9 \pm 0.22 \%$ in $\mathrm{L} 3.6 \mathrm{pl}$, to $5.38 \pm 0.99 \%$ in the L3.6 $\mathrm{pl}_{\text {Gres }}$ cells in response to continuous gemcitabine treatment. This proportion of SP cells could be diminished by treatment with verapamil hydrochloride. In the AsPC-1 cell line, $21.35 \pm 3.48 \%$ SP cells were identified, which was found to diminish to $3.56 \pm 0.87 \%$ in response to verapamil blockade $\left(\mathrm{p}<5 \mathrm{E}^{-10}\right)$ (Fig. 2).

We then compared the colony formation ability of L3.6 $\mathrm{pl}_{\mathrm{Gres}}$, L3.6pl, as well as L3.6 $\mathrm{pl}_{\mathrm{Gres}}-\mathrm{SP}$ and NSP cells. The assay showed that $\mathrm{L} 3.6 \mathrm{pl}_{\text {Gres }}$ cells and $\mathrm{L} 3.6 \mathrm{pl}_{\mathrm{Gres}}-\mathrm{SP}$ cells have significantly higher colony formation ability, and thus enhanced CSC-like characteristics when compared to the L3.6pl or L3.6pl $\mathrm{Gres}_{\mathrm{N}} \mathrm{NSP}$ cells (Fig. 3). 


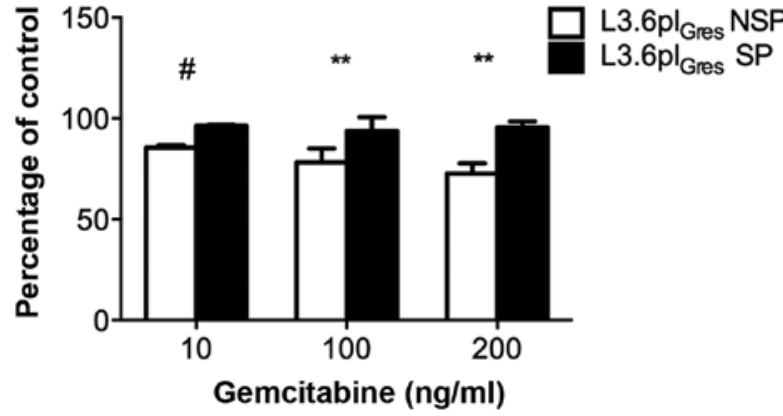

Figure 4.L3.6pl $\mathrm{Gres}_{\mathrm{Gres}}-\mathrm{SP}$ cells are more resistant to gemcitabine than $\mathrm{L} 3.6 \mathrm{pl}_{\mathrm{Gres}}-\mathrm{NSP}$ cells. Immediately after FACS sorting, SP as well as NSP subpopulation cells from $\mathrm{L} 3.6 \mathrm{pl}_{\mathrm{Gres}}$ were seeded. Different concentrations of gemcitabine were applied over $24 \mathrm{~h}$. L3.6pl $\mathrm{p}_{\text {Gres }} \mathrm{SP}$ cells maintained their gemcitabine resistance compared to NSP cells $\left({ }^{*} \mathrm{p}<0.01,{ }^{* *} \mathrm{p}<0.0001\right)$.

The gemcitabine resistance of $\mathrm{L} 3.6 \mathrm{pl}_{\text {Gres }}$ cells was further validated by cell viability assays. The results show that L3.6pl $\mathrm{Gres}_{\text {in }}$ SP cells have enhanced resistance to gemcitabine relative to respective NSP cells (Fig. 4).

Verapamil can effectively inhibit L3.6pl $l_{\text {Gres }}$ and AsPC-1 SP cell proliferation. Since the percentage of SP cells in the parental L3.6pl cell line was relatively low, it was difficult to harvest sufficient cell numbers by FACS sorting for cell proliferation assays. Therefore, the proliferation capacity of the $\mathrm{L} 3.6 \mathrm{pl}_{\mathrm{Gres}}$ cell line (enriched SP cells) was compared to control L3.6pl cells. In parallel, the SP and Non-SP cells from the AsPC-1 cell line were directly compared.

To investigate whether verapamil alone is effective against SP cells, we analyzed its effect on L3.6pl- and $\mathrm{L} 3.6 \mathrm{pl}_{\text {Gres }}{ }^{-}$, AsPC-1-SP and -NSP cell proliferation. All of the cell lines tested showed a concentration-dependent reduction in cell proliferation. In response to 50,100, 150 and $200 \mu \mathrm{M}$ of verapamil, the $\mathrm{L} 3.6 \mathrm{pl}_{\mathrm{Gres}^{-}}$and AsPC-1-SP cells were more sensitive to verapamil effects than L3.6pl- and AsPC-1-NSP cells (Fig. 5).

Pro-apoptotic effect of verapamil in combination with gemcitabine in L3.6pl and L3.6pl $l_{\text {Gres }}$ cells. The potential additive effect of verapamil in combination with gemcitabine was then investigated. $\mathrm{L} 3.6 \mathrm{pl}_{\text {Gres }}$-SP cells were treated separately with verapamil $(50 \mu \mathrm{M})$, gemcitabine $(10 \mathrm{ng} / \mathrm{ml})$, and in combination. Using FACS analysis, the level of apoptotic cells after combined treatment (at $24 \mathrm{~h}$ ) was found to increase relative to treatment with verapamil or gemcitabine alone (Fig. 6A). In dose response experiments, the apoptosis of L3.6pl and L3.6pl $\mathrm{Gres}_{\text {res }}$ cells in response to increasing concentrations of gemcitabine was determined, while maintaining the concentration of verapamil at $50 \mu \mathrm{M}$. A dose-dependent increase in apoptosis was observed in L3.6pl cells, but not in the $\mathrm{L} 3.6 \mathrm{pl}_{\text {Gres }}$ cells (Fig. 6B and C).

The expression level of drug transporter proteins in L3.6pl and $L 3.6 l_{\text {Gres }}$. The expression of the drug transporter proteins P-gp and ENT1 were then analyzed by western blotting. The results revealed that the expression of $\mathrm{P}$-gp was increased in L3.6pl $\mathrm{Gres}_{\text {Gel }}$ cells as compared to L3.6pl cells, while expression
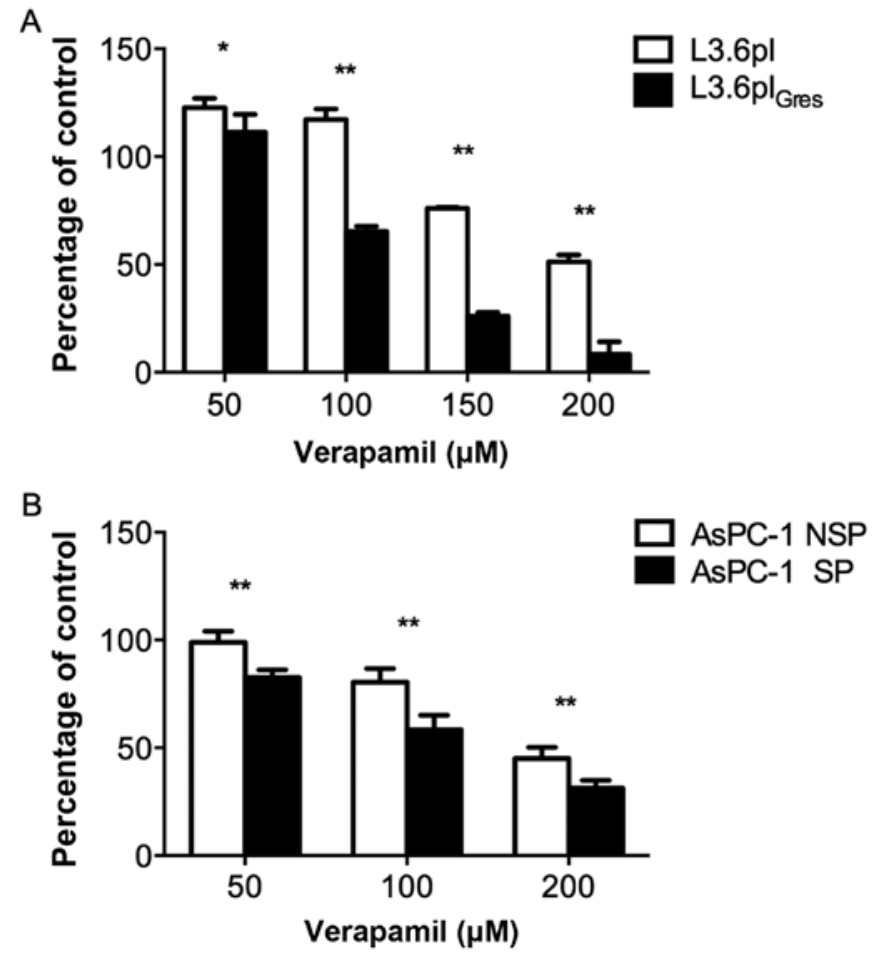

Figure 5. Verapamil alone can effectively inhibit the proliferation of $\mathrm{L}^{3} .6 \mathrm{pl}_{\mathrm{Gres}}$ and AsPC-1 SP cells in vitro. (A) Treatment of L3.6pl and $\mathrm{L} 3.6 \mathrm{pl}_{\mathrm{Gres}}$ cells for $24 \mathrm{~h}$ with increasing concentrations of verapamil led to a dose-dependent significant reduction of cell proliferation in $\mathrm{L} 3.6 \mathrm{pl}_{\mathrm{Gres}}$ cells, which was much more sensitive to verapamil than L3.6pl cells $\left({ }^{*} \mathrm{p}<0.001,{ }^{* *} \mathrm{p}<0.0001\right)$. (B) FACS sorted SP and NSP AsPC-1 cells were treated with increasing concentrations of verapamil. Cell proliferation was significantly reduced in AsPC-1-SP cells than AsPC-1-NSP cells ( $\left.{ }^{* *} \mathrm{p}<0.0001\right)$.

of ENT1 in L3.6pl $\mathrm{Gres}_{\text {rells }}$ was found to be substantially lower than in L3.6pl cells. The expression of P-gp in both cell lines was found to decrease after 24-hour treatment with verapamil $(50 \mu \mathrm{M})$, and in particular, showed a marked reduction in the

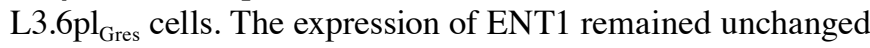
after verapamil treatment (Fig. 7).

Verapamil can effectively inhibit L3.6pl $l_{\text {Gres }}$-SP tumor growth in vivo. $\mathrm{L} 3.6 \mathrm{pl}_{\mathrm{Gres}}-\mathrm{SP}$ and NSP cells were injected into the pancreas of athymic Balb/c nu/nu mice. The following experimental groups were compared: group 1, L3.6pl $\mathrm{Gres}_{\text {-SP control }}$ group (5 mice); group 2, $\mathrm{L} 3.6 \mathrm{pl}_{\text {Gres }}$-NSP cell control group (3 mice); group 3, $\mathrm{L} 3.6 \mathrm{pl}_{\mathrm{Gres}}$-SP treatment group with high concentration of verapamil ( $25 \mathrm{mg} / \mathrm{kg} \mathrm{BW}, 10 \mathrm{mM}, 3$ mice); and group 4, L3.6pl $\mathrm{Gres}_{\text {SP }}$-SP treatment group with low concentration of verapamil $(0.5 \mathrm{mg} / \mathrm{kg} \mathrm{BW}, 200 \mu \mathrm{M}, 4$ mice). In all groups, verapamil treatment was initiated four weeks after orthotopic tumor cell injection. Nine weeks later all the mice were sacrificed. Tumors and other organs were then harvested for analysis.

Macroscopically, the L3.6pl $\mathrm{Gres}_{\mathrm{Ge}}-\mathrm{SP}$ tumors showed a more aggressive phenotype compared to the $\mathrm{L} 3.6 \mathrm{pl}_{\text {Gres }}$-NSP tumors. Verapamil treatment (low/high concentrations) substantially inhibited tumor growth and metastasis of the $\mathrm{L} 3.6 \mathrm{pl}_{\mathrm{Gres}}-\mathrm{SP}$ cells (Fig. 8). No changes in body weight, or general behavior were observed in the verapamil treatment groups (groups 3 and 4). 
A

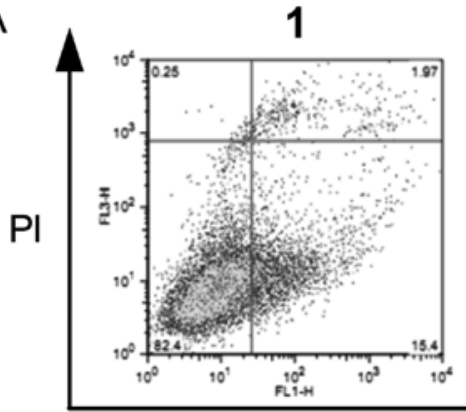

2

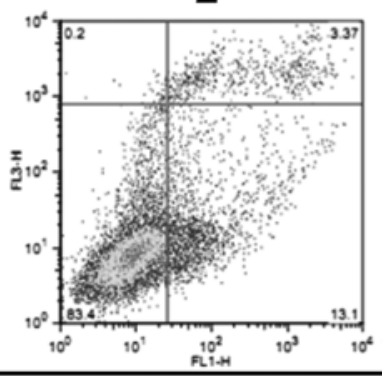

Anneix-V-FITC
3

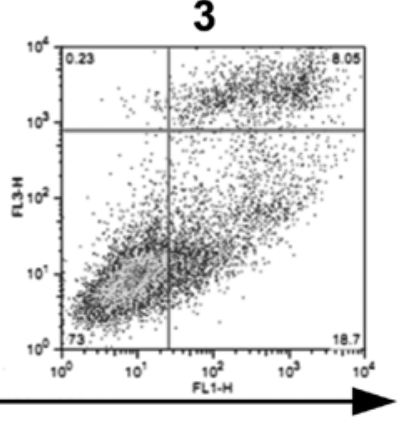

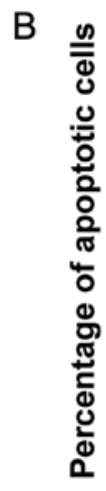

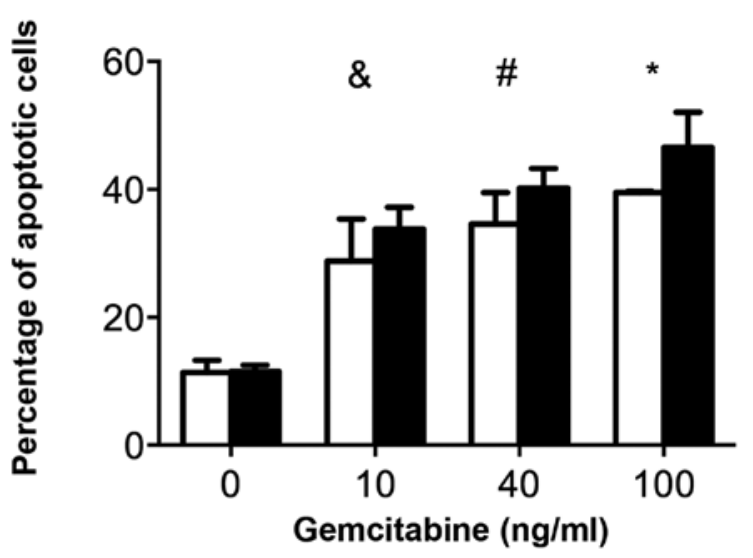

C

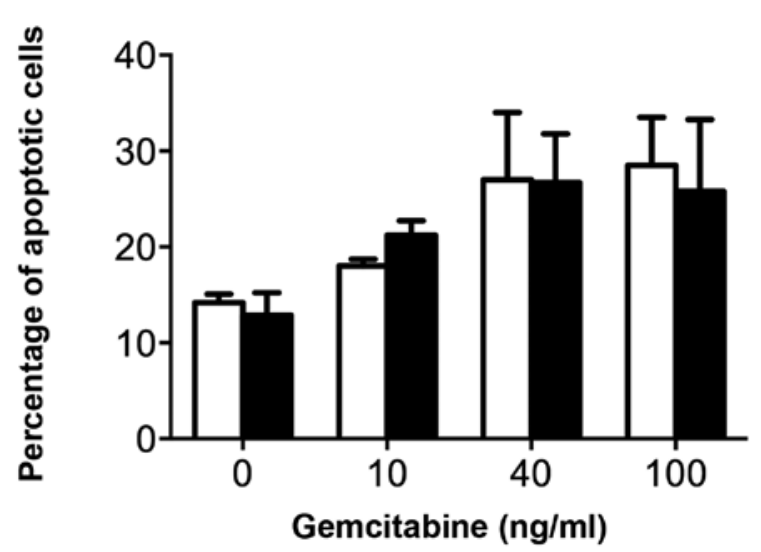

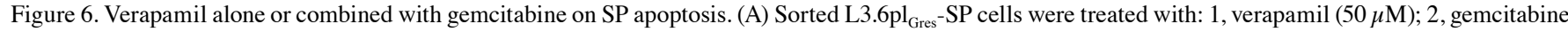
$(10 \mathrm{ng} / \mathrm{ml})$; or 3, verapamil $(50 \mu \mathrm{M})$ combined with gemcitabine $(10 \mathrm{ng} / \mathrm{ml})$ for $24 \mathrm{~h}$. Compared to verapamil and gemcitabine treatment alone the proportion

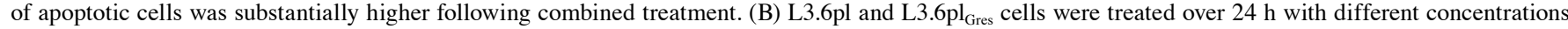
of gemcitabine $(0,10,40$ and $100 \mathrm{ng} / \mathrm{ml})$ alone or in combination with verapamil $(50 \mu \mathrm{M})$. Under combination therapy, the proportion of apoptotic L3.6pl cells increased in a dose-dependent manner $\left({ }^{\circledR} \mathrm{p}<0.05,{ }^{\sharp} \mathrm{p}<0.01,{ }^{*} \mathrm{p}<0.001\right)$. (C) The percentage of apoptotic L3.6pl $\mathrm{Gres}_{\text {was }}$ only slightly increasing following combination therapy.

Immunohistochemical staining was used to establish a proliferation index, microvascular density, and apoptosis level in the experimental pancreatic tumors derived from the

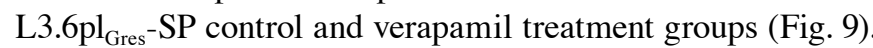
The median percentage of $\mathrm{Ki} 67^{+}$cells within the tumors of the verapamil treatment group differed slightly from that seen in the $\mathrm{L} 3.6 \mathrm{pl}_{\text {Gres }}$-SP group. The apoptotic signal was increased in the verapamil treatment group as compared to the $\mathrm{L} 3.6 \mathrm{pl}_{\mathrm{Gres}}-\mathrm{SP}$ control group. The microvascular density measured by CD31 staining revealed significantly reduced angiogenesis in tumors following verapamil treatment, as compared to the $\mathrm{L} 3.6 \mathrm{pl}_{\mathrm{Gres}}-\mathrm{SP}$ tumors in the control group. H\&E staining showed large, pleomorphic cells with hyperchromatic nuclei in the $\mathrm{L} 3.6 \mathrm{pl}_{\mathrm{Gres}}-\mathrm{SP}$ control group.

\section{Discussion}

The general concept of cancer stem cells (CSCs) is a topic of increasing clinical interest. CSCs are proposed to show stem-like self-renewal and tumor initiation characteristics that are thought to help foster tumor recurrence and resistance to chemotherapy. CSCs can be enriched by several methods including by growth in serum-free defined media to induce sphere formation. They can also be directly isolated based on 

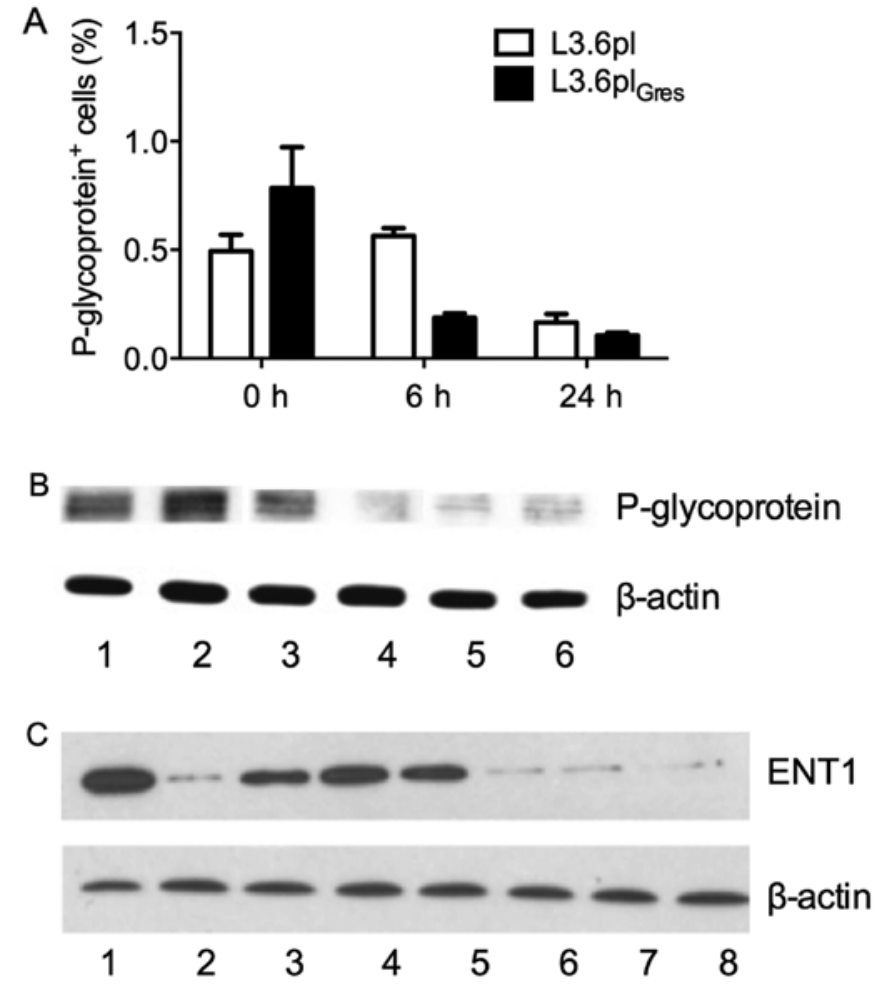

Figure 7. Expression of drug transporter proteins in $\mathrm{L} 3.6 \mathrm{pl}$ and $\mathrm{L} 3.6 \mathrm{pl}_{\text {Gres }}$. (A) After treatment of $\mathrm{L} 3.6 \mathrm{pl}$ and $\mathrm{L} 3.6 \mathrm{pl}_{\text {Gres }}$ cells with verapamil $(50 \mu \mathrm{M})$ for 0,6 and $24 \mathrm{~h}$, all cells were analyzed by FACS. The proportion of P-glycoprotein positive cells decreased after treatment in both cell lines, however, significantly more in $\mathrm{L} 3.6 \mathrm{pl}_{\text {Gres }}(\mathrm{p}<0.01)$. (B) The protein lysates from: 1, L3.6pl; 2, $\mathrm{L} 3.6 \mathrm{pl}_{\text {Gres }} ; 3, \mathrm{~L} 3.6 \mathrm{pl}$ treated with verapamil $(50 \mu \mathrm{M})$ for $6 \mathrm{~h} ; 4, \mathrm{~L} 3.6 \mathrm{pl}$ treated with verapamil $(50 \mu \mathrm{M})$ for $24 \mathrm{~h} ; 5, \mathrm{~L}_{3} .6 \mathrm{pl}_{\mathrm{Gres}}$ treated with verapamil $(50 \mu \mathrm{M})$ for $6 \mathrm{~h} ; 6, \mathrm{~L} 3.6 \mathrm{pl}_{\text {Gres }}$ treated with verapamil $(50 \mu \mathrm{M})$ for $24 \mathrm{~h}$. The expression of P-glycoprotein was significantly higher in $\mathrm{L} 3.6 \mathrm{pl}_{\text {Gres }}$, than L3.6pl cells. Under treatment of verapamil for $24 \mathrm{~h}$, the expression level of P-glycoprotein decreased in both cell lines, and showed a marked reduction in the $\mathrm{L} 3.6 \mathrm{pl}_{\text {Gres }}$ cells. (C) The expression level of ENT1 before/after verapamil treatment in $\mathrm{L} 3.6 \mathrm{pl}$ and $\mathrm{L} 3.6 \mathrm{pl}_{\text {Gres }}$ cells. The protein lysates from: 1, L3.6pl; 2, $\mathrm{L}_{3} .6 \mathrm{pl}_{\text {Gres }} ; 3, \mathrm{~L} 3.6 \mathrm{pl}$ treated with verapamil $(50 \mu \mathrm{M})$ for $24 \mathrm{~h} ; 4, \mathrm{~L} 3.6 \mathrm{pl}$ treated with verapamil $(100 \mu \mathrm{M})$ for $24 \mathrm{~h} ; 5, \mathrm{~L} 3.6 \mathrm{pl}$ treated with verapamil $(200 \mu \mathrm{M})$ for $24 \mathrm{~h} ; 6, \mathrm{~L}_{3} .6 \mathrm{pl}_{\mathrm{Gres}}$ treated with verapamil $(50 \mu \mathrm{M})$ for $24 \mathrm{~h} ; 7, \mathrm{~L}_{3} .6 \mathrm{pl}_{\mathrm{Gres}}$ treated with verapamil $(100 \mu \mathrm{M})$ for $24 \mathrm{~h}$; $8, \mathrm{~L} .6 \mathrm{pl}_{\text {Gres }}$ treated with verapamil $(200 \mu \mathrm{M})$ for $24 \mathrm{~h}$. The results indicate that the expression of ENT1 was lower in L3.6pl $\mathrm{Gres}_{\text {s }}$ cells than in L3.6pl cells, and were unchanged under different concentrations $(50,100$ and $200 \mu \mathrm{M})$ of verapamil.

their expression of specific surface marker combinations, i.e., $\mathrm{CD} 44^{+} / \mathrm{CD} 24-/$ lin- for human breast cancers (35), $\mathrm{EpCAM}^{\text {high/ }}$ $\mathrm{CD} 44^{+} / \mathrm{CD} 166^{+}$for colorectal cancer (36), $\mathrm{CD} 34^{+} / \mathrm{CD} 38^{-}$for acute myeloid leukemia (37), and $\mathrm{Strol}^{+} / \mathrm{CD} 05^{+} / \mathrm{CD} 44^{+}$, a surface marker for bone sarcoma (38). CSC subpopulations can also be isolated by FACS sorting of side population (SP) cells based on their ability to efflux fluorescent dyes or chemotherapy reagents (39). SP cells have been widely linked to CSCs in various tumors and cancer cell lines, e.g., acute myeloid leukemia (40), neuroblastoma (19), melanoma (41), ovarian cancer (42), glioma cell lines (43), various human gastrointestinal cancer cell lines (44), and pancreatic cancer cell lines, including; MIAPaCa2, PANC-1, Capan-2, KP-1 NL and SW1990 (23,45-47).

In this study, we isolated and characterized SP cells from a highly metastatic pancreatic adenocarcinoma cell line L3.6pl, a chemotherapy-resistant variant of this line $\mathrm{L} 3.6 \mathrm{pl}_{\mathrm{Gres}}$, and from the AsPC-1 human pancreatic cell line (Fig. 2).

The SP-enriched L3.6 $\mathrm{pl}_{\text {Gres }}$ cells, which were shown in a previous study to have significantly increased $\mathrm{ABCG}^{+}$, and $\mathrm{CD} 24^{+}$cells, showed higher colony formation ability in vitro

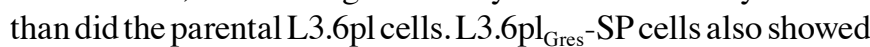
increased colony formation ability relative to $\mathrm{L} 3.6 \mathrm{pl}_{\text {Gres }}-\mathrm{NSP}$ cells (Fig. 3) and exhibited increased gemcitabine chemotherapy resistance relative to the $\mathrm{L} 3.6 \mathrm{pl}_{\mathrm{Gres}}-\mathrm{NSP}$ cells suggesting enhanced stem cell-like properties (Fig. 4). SP and non-SP of AsPC-1 did not work as a good model for stem cell like SP study by our previous data (data not shown). SP proportion is highly abound in AsPC-1 and did not show statistic significance in tumorigenicity in vivo. Therefore, in this study, we focused on SP cells from L3.6pl and its corresponding resistant variant.

These observations were then validated in vivo. Following orthotopic implantation, significantly larger primary pancreatic tumors, and a higher incidence of liver metastases, were found in the $\mathrm{L} 3.6 \mathrm{pl}_{\mathrm{Gres}}-\mathrm{SP}$ cells, as compared to $\mathrm{L} 3.6 \mathrm{pl}_{\mathrm{Gres}}-\mathrm{NSP}$ cells, supporting the hypothesis that they show enhanced stem cell-like characteristics (Fig. 9).

Morphologic changes were associated with the establishment of gemcitabine-resistant L3.6pl cells. A fibroblastoid phenotype with loss of polarity, increased intercellular separation and pseudopodia was detected in the $\mathrm{L} 3.6 \mathrm{pl}_{\text {Gres }}$ cells (Fig. 1). This observation is consistent with the phenomenon of epithelial-to-mesenchymal transition (EMT). Molecular and phenotypic associations have been previously linked to the establishment of chemoresistance including the acquisition of an EMT-like cancer cell phenotype (48). SP cells have been previously associated with chemotherapy resistance and enhanced EMT $(49,50)$.

Goodell et al (16) have shown that the molecular pumps responsible for $\mathrm{H} 33342$ efflux (used to differentiate SP from NSP cells) are generally members of the ABC superfamily including MDR1/P-gp, ABCG2, and MRP (7-9,51). Verapamil, the first generation P-gp inhibitor, has been reported to block dye efflux activity and potentially reverse the drug resistance caused by expression of P-gp (26). We show that verapamil effectively reduces Hoechst 33342 staining of FACS-associated SP cells in L3.6pl, L3.6pl $\mathrm{Gres}_{\text {,es }}$, and AsPC-1 cell lines (Fig. 2). Verapamil appears to target important characteristics associated with $\mathrm{CRC} / \mathrm{SP}$ cells and may therefore show therapeutic efficacy for treating pancreatic cancer stem cells. We found that verapamil could also directly inhibit cell proliferation in a dose-dependent manner in vitro, and was able to inhibit SP cells more efficiently than NSP cells in both pancreatic cell lines tested (L3.6pl $\mathrm{Gres}_{\text {res }}$ and AsPC-1) (Fig. 5). Verapamil was further found to effectively prevent $\mathrm{L} 3.6 \mathrm{pl}_{\mathrm{Gres}}-\mathrm{SP}$ tumor growth in orthotopic in vivo tumor models (Fig. 8 and Table I). For a potential side effect, we checked the mice by bodyweight regular detection and animal behaviour, and speculated that no serious side effects existed. It is a limitation in this study that we did not have more biochemical parameters for a better evaluation of side effect.

The direct effects of verapamil on pancreatic cancer cells seen are supported by earlier reports that showed verapamil inhibition of proliferation and induced differentiation of human promyelocytic HL-60 cells (52), a growth inhibitory 
A

L3.6pl $\mathrm{Gres}-\mathrm{SP}$
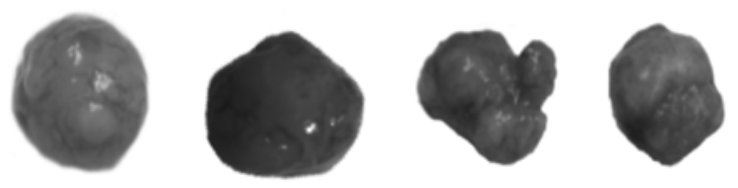

L3.6pl $\mathrm{Gres}^{-\mathrm{NSP}}$
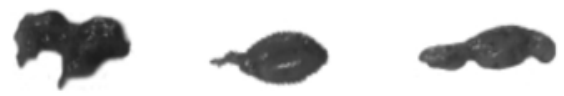

$$
\begin{aligned}
& \text { L3.6pl }_{\text {Gres }} \text {-SP } \\
& + \text { vera }
\end{aligned}
$$

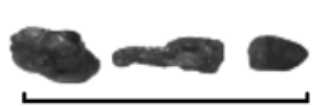

High dose
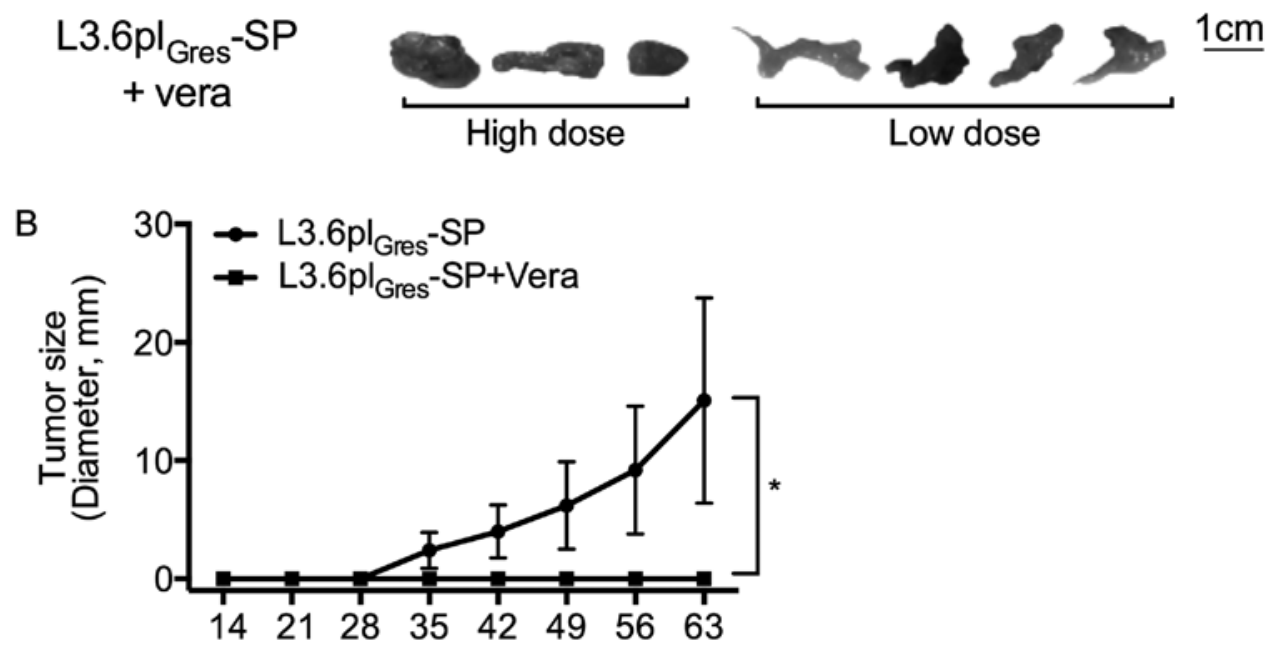

Day

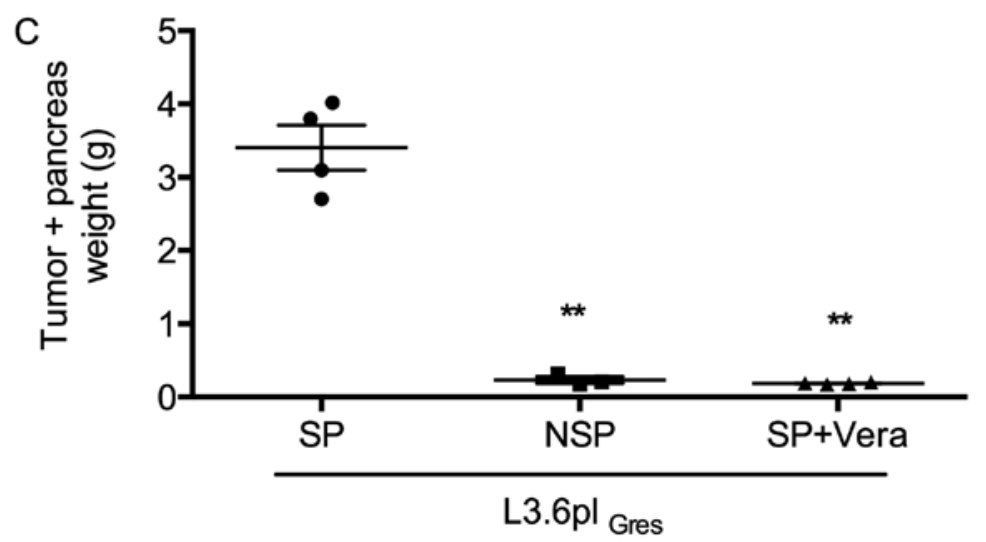

Figure 8. Verapamil therapy suppresses tumor growth induced by L3.6pl $\mathrm{Gres}_{\mathrm{GeS}} \mathrm{SP}$ cells in an orthotopic human pancreatic cancer nude mouse model. Verapamil treatment significantly inhibited tumor growth in a dose-independent manner. (A) Macroscopic analysis of tumors from L3.6pl $\mathrm{Gres}_{\mathrm{Ges}}-\mathrm{SP}$ cells, L3.6pl $\mathrm{Gres}-\mathrm{NSP}$ cells and $\mathrm{L} 3.6 \mathrm{pl}_{\mathrm{Gres}}-\mathrm{SP}$ cells with verapamil treatment (53). Verapamil resulted in a significant reduction of primary pancreatic tumor growth in a nude mouse model. (B) Tumor growth curves (depicted as longest diameter of a two-dimensional transcutaneous measurement) of L3.6pl $\mathrm{fres}_{\text {Ges }}$-SP cell implanted mice and mice under verapamil treatment. (C) Primary pancreatic tumor weight (including normal pancreatic tissue) upon sacrifice depicted as mean \pm SD $\left(^{* *} \mathrm{p}<0.0001\right)$.

Table I. The incidence of primary pancreatic tumors as well as metastatic spread in $\mathrm{L} 3.6 \mathrm{pl}_{\mathrm{Gres}} \mathrm{SP}, \mathrm{L} 3.6 \mathrm{pl} \mathrm{Gres}_{\mathrm{Ge}}-\mathrm{NSP}$ and the therapy groups is indicated. ${ }^{\mathrm{a}}$

\begin{tabular}{lcccc}
\hline & & \multicolumn{2}{c}{$\mathrm{L3.6pl}_{\text {Gres }}$} \\
\cline { 3 - 5 } Group & & \multicolumn{2}{c}{$\mathrm{SP}+$ verapamil } \\
\cline { 3 - 5 } \cline { 3 - 4 } Primary tumor & $4 / 5$ & $0 / 4$ & $1 / 3$ & $0 / 3$ \\
Liver metastasis & $2 / 5$ & $2 / 4$ & $0 / 3$ & $0 / 3$ \\
\hline
\end{tabular}

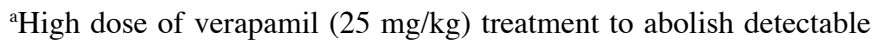
primary tumor and metastatic lesions. effect on human colonic tumor cells (54), and antiproliferative effects on brain tumor cells in vitro (55). A reversible, antiproliferative action of verapamil on human medulloblastoma, pinealoblastoma, glioma, and neuroblastoma tumor lines has also been reported (55).

SP cells isolated from L3.6pl $1_{\text {Gres }}$ and AsPC-1 cell lines were more sensitive to verapamil than NSP cells. SP-enriched L3.6pl $\mathrm{Gres}_{\text {Gre }}$ cells expressed higher levels of P-gp than NSP L3.6pl cells. Verapamil treatment of $\mathrm{L} 3.6 \mathrm{pl}_{\text {Gres }}$ cells led to a significant reduction in $\mathrm{P}$-gp expression as compared to $\mathrm{L} 3.6 \mathrm{pl}$ cells (Fig. 7), which may explain in part the targeted effect of verapamil detected in SP cells.

Pro-apoptotic effects of verapamil were demonstrated by in vitro apoptosis assays (Fig. 6) and by ex vivo immunohistochemistry analysis of the tumor samples (Fig. 9). This enhanced 

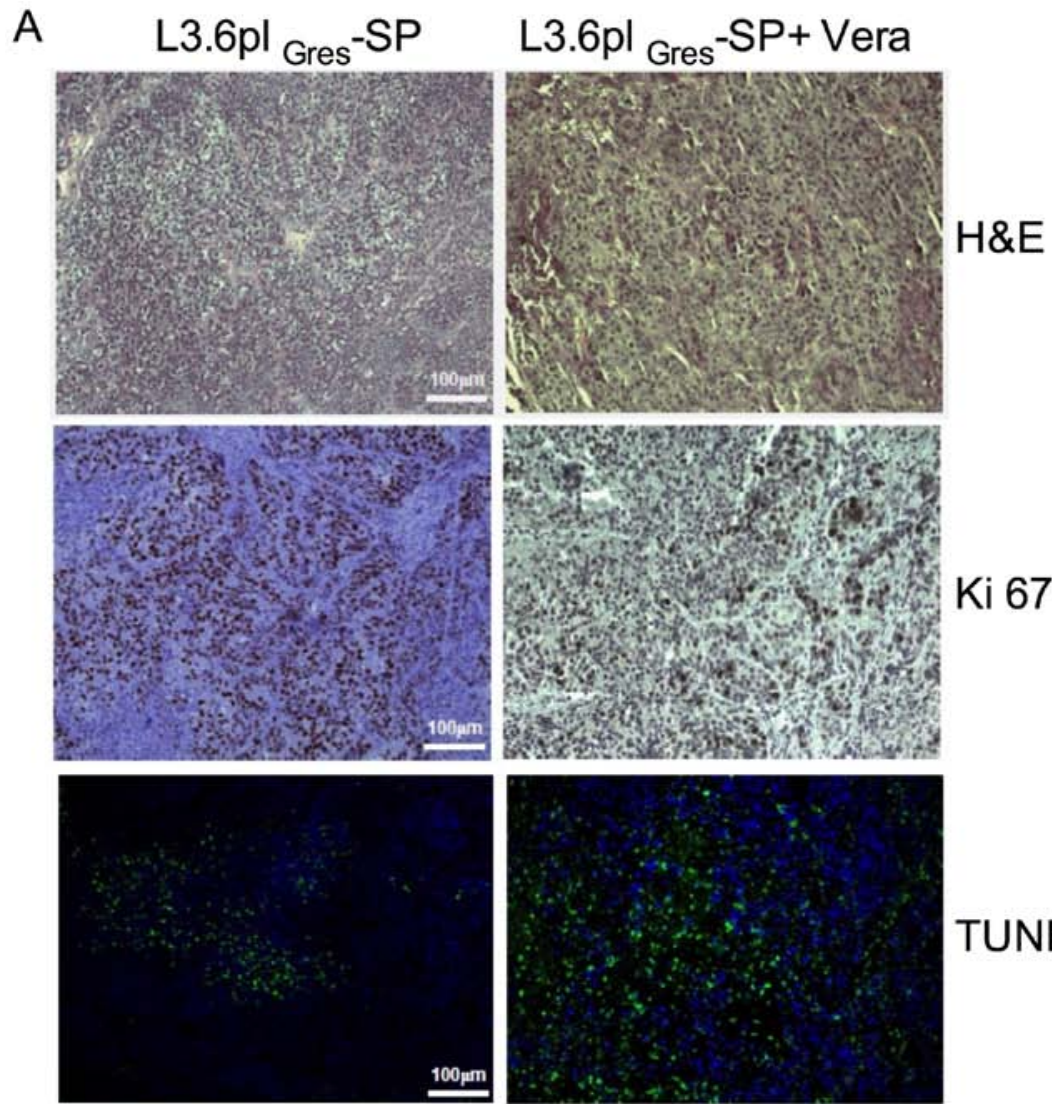

\section{Ki 67}

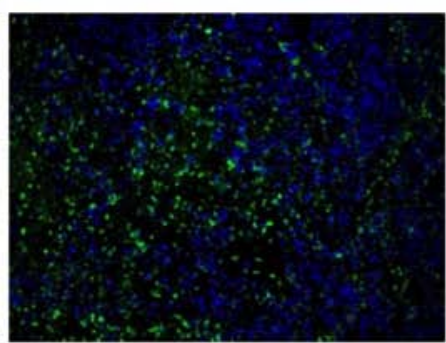

\section{TUNEL}
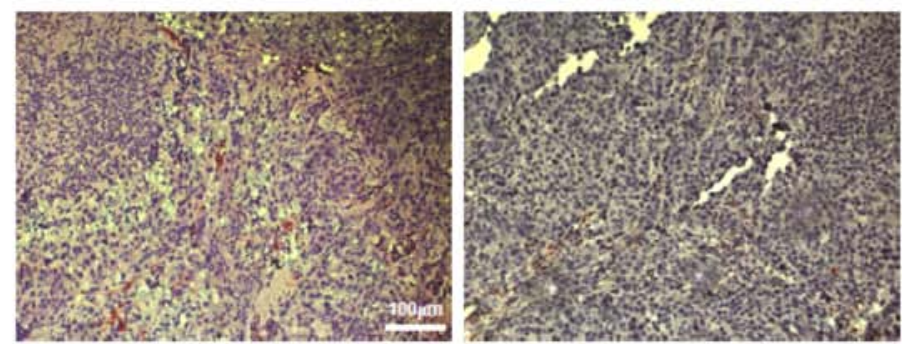

B
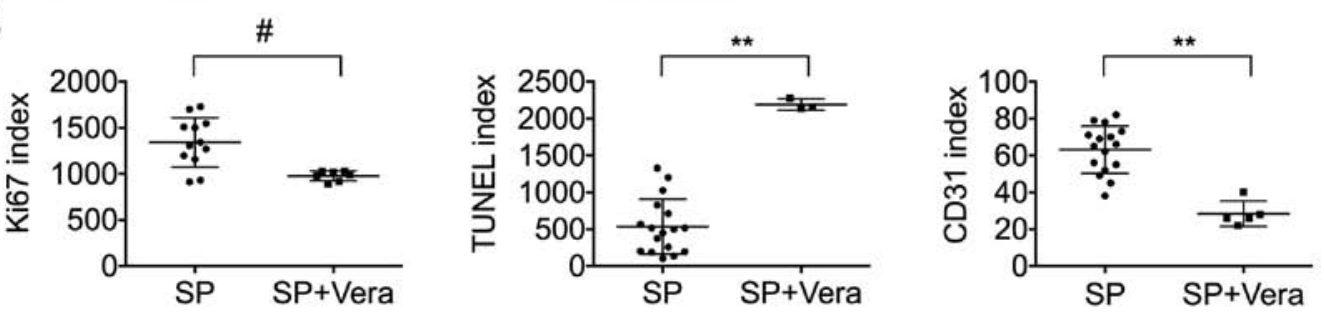

Figure 9. Immunohistochemical analysis of $\mathrm{L} 3.6 \mathrm{pl}_{\mathrm{Gres}}-\mathrm{SP}$ induced tumors following verapamil treatment. H\&E staining showed large, pleomorphic cells with hyperchromatic nuclei in the $\mathrm{L} 3.6 \mathrm{pl}_{\mathrm{Gres}}-\mathrm{SP}$ control group, while the normal, round, light nuclei composed most of the tumor tissue in the verapamil treatment group. $\mathrm{Ki} \mathrm{7}^{+}$signals are manifested by dark brown stained cells (53). The scatter plot of Ki67 index shows that the median percentage of Ki67 ${ }^{+}$proliferating cells within tumors of the verapamil treatment group decreased from that of the $\mathrm{L} 3.6 \mathrm{pl}_{\mathrm{Gres}}-\mathrm{SP}$ control group $\left({ }^{\sharp} \mathrm{p}=0.0027\right)$. TUNEL assay was used for apoptosis Apoptotic cells are stained with fluorescent green. The scatter plot of the TUNEL index shows that the number of apoptotic cells in the verapamil treatment group is significantly higher than in $\mathrm{L} 3.6 \mathrm{pl}_{\mathrm{Gres}}-\mathrm{SP}$ control group ( $\left.{ }^{* *} \mathrm{p}<0.0001\right)$. Immunohistochemical staining for CD31 was applied for detection of microvessel density. The red stained portions in the images are endothelial cells lining the vessels following anti-CD31 labeling. The scatter plot of microvessel density shows that the average microvessel density in the verapamil treatment group is significantly reduced compared to the $\mathrm{L} 3.6 \mathrm{pl} \mathrm{Gres}_{\mathrm{S}}-\mathrm{SP}$ control group $\left({ }^{* *} \mathrm{p}<0.0001\right)$.

apoptosis by verapamil may be explained by its actions as a calcium channel antagonist $(52,54)$. Calcium ions $\left(\mathrm{Ca}^{2+}\right)$ are cellular messengers that control cell and tissue physiology, and potentially 'death' signals $(55,56)$. Calcium antagonists disrupt intracellular and extracellular $\mathrm{Ca}^{2+}$ equilibrium (57). $\mathrm{Ca}^{2+}$ is toxic at high concentrations, thus verapamil may help to foster apoptosis though disruption of the $\mathrm{Ca}^{2+}$ balance.
Other $\mathrm{ABC}$ superfamily members are also thought to contribute to SP chemotherapy resistance. Recently it was shown that verapamil and its derivative- $\mathrm{NMeOHI}(2)$ can trigger apoptosis though glutathione (GSH) extrusion mediated by MRP1 (58). The loss of GSH from cells can result in increased oxidative stress, a well-recognized trigger for apoptosis (59). 
Although verapamil can enhance cytotoxicity when used in combination with chemotherapy agents, such as anthracyclines (28), paclitaxel (60), epipodophyllotoxins (61) and melphalan (62), little is known about the potential effects of verapamil when used alone or in combination with gemcitabine, the standard chemotherapy reagent for pancreatic cancer. We identified combined pro-apoptotic effects of verapamil and gemcitabine on L3.6pl but not on $\mathrm{L} 3.6 \mathrm{pl}_{\text {Gres }}$ cells. This may be explained in part by the expression level of ENT1, a major transporter for gemcitabine that was substantially lower in $\mathrm{L} 3.6 \mathrm{pl}_{\mathrm{Gres}}$ cells compared to L3.6pl cells. The absence of ENT1 is also associated with a reduced survival in patients with gemcitabine treated pancreatic adenocarcinoma (63).

In conclusion, this study revealed that verapamil may act on pancreatic cancer cells in vitro by inhibiting P-gp transporters and inducing apoptosis of stem-like SP cells in L3.6pl, L3.6 $\mathrm{pl}_{\text {Gres }}$ and AsPC-1 cells. Verapamil can significantly inhibit pancreatic cancer tumor growth in vivo potentially by targeting stem-like side population cells.

\section{Acknowledgements}

The authors thank Anneli Tischmacher for her technical assistance. This study was supported by the German Research Society (DFG) grant BR 1614/7-1 and the DKTK/DKFZ 2013 ('Stem cells in Oncology') to C.J.B. L.Z., Y.Z. and Q.B. were supported by LMU-CSC (The China Scholarship Council) scholarship.

\section{References}

1. Jemal A, Siegel R, Ward E, Hao Y, Xu J and Thun MJ: Cancer statistics, 2009. CA Cancer J Clin 59: 225-249, 2009.

2. Fernandez E, La Vecchia C, Porta M, Negri E, Lucchini F and Levi F: Trends in pancreatic cancer mortality in Europe, 1955-1989. Int J Cancer 57: 786-792, 1994.

3. Chen M, Xue X, Wang F, An Y, Tang D, Xu Y, Wang H, Yuan Z, Gao W, Wei J, et al: Expression and promoter methylation analysis of ATP-binding cassette genes in pancreatic cancer. Oncol Rep 27: 265-269, 2012.

4. Arbuck SG: Overview of chemotherapy for pancreatic cancer. Int J Pancreatol 7: 209-222, 1990.

5. Suwa $\mathrm{H}$, Ohshio $\mathrm{G}$, Arao $\mathrm{S}$, Imamura $\mathrm{T}$, Yamaki $\mathrm{K}$, Manabe $\mathrm{T}$, Imamura M, Hiai $\mathrm{H}$ and Fukumoto M: Immunohistochemical localization of P-glycoprotein and expression of the multidrug resistance-1 gene in human pancreatic cancer: Relevance to indicator of better prognosis. Jpn J Cancer Res 87: 641-649, 1996.

6. Grant CE, Valdimarsson G, Hipfner DR, Almquist KC, Cole SP and Deeley RG: Overexpression of multidrug resistance-associated protein (MRP) increases resistance to natural product drugs. Cancer Res 54: 357-361, 1994.

7. Germann UA, Chambers TC, Ambudkar SV, Licht T, Cardarelli CO, Pastan I and Gottesman MM: Characterization of phosphorylation-defective mutants of human P-glycoprotein expressed in mammalian cells. J Biol Chem 271: 1708-1716, 1996.

8. Childs S and Ling V: The MDR superfamily of genes and its biological implications. Important Adv Oncol: 21-36, 1994.

9. Chin KV, Pastan I and Gottesman MM: Function and regulation of the human multidrug resistance gene. Adv Cancer Res 60: $157-180,1993$

10. Thomas $\mathrm{H}$ and Coley HM: Overcoming multidrug resistance in cancer: an update on the clinical strategy of inhibiting P-glycoprotein. Cancer Control 10: 159-165, 2003.

11. Hagmann W, Jesnowski R and Löhr JM: Interdependence of gemcitabine treatment, transporter expression, and resistance in human pancreatic carcinoma cells. Neoplasia 12: 740-747, 2010 .
12. Mackey JR, Mani RS, Selner M, Mowles D, Young JD, Belt JA, Crawford CR and Cass CE: Functional nucleoside transporters are required for gemcitabine influx and manifestation of toxicity in cancer cell lines. Cancer Res 58: 4349-4357, 1998.

13. Ritzel MW, Ng AM, Yao SY, Graham K, Loewen SK, Smith KM, Ritzel RG, Mowles DA, Carpenter P, Chen XZ, et al: Molecular identification and characterization of novel human and mouse concentrative $\mathrm{Na}^{+}$-nucleoside cotransporter proteins (hCNT3 and mCNT3) broadly selective for purine and pyrimidine nucleosides (system cib). J Biol Chem 276: 2914-2927, 2001.

14. Garcia-Manteiga J, Molina-Arcas M, Casado FJ, Mazo A and Pastor-Anglada M: Nucleoside transporter profiles in human pancreatic cancer cells: Role of hCNT1 in 2',2'-difluorodeoxycytidine- induced cytotoxicity. Clin Cancer Res 9: 5000-5008, 2003.

15. Al-Hajj M and Clarke MF: Self-renewal and solid tumor stem cells. Oncogene 23: 7274-7282, 2004.

16. Goodell MA, Brose K, Paradis G, Conner AS and Mulligan RC: Isolation and functional properties of murine hematopoietic stem cells that are replicating in vivo. J Exp Med 183: 1797-1806, 1996.

17. Bunting KD, Zhou S, Lu T and Sorrentino BP: Enforced P-glycoprotein pump function in murine bone marrow cells results in expansion of side population stem cells in vitro and repopulating cells in vivo. Blood 96: 902-909, 2000.

18. Zhou S, Schuetz JD, Bunting KD, Colapietro AM, Sampath J, Morris JJ, Lagutina I, Grosveld GC, Osawa M, Nakauchi H, et al: The ABC transporter Bcrp1/ABCG2 is expressed in a wide variety of stem cells and is a molecular determinant of the sidepopulation phenotype. Nat Med 7: 1028-1034, 2001.

19. Hirschmann-Jax C, Foster AE, Wulf GG, Nuchtern JG, Jax TW, Gobel U, Goodell MA and Brenner MK: A distinct 'side population' of cells with high drug efflux capacity in human tumor cells. Proc Natl Acad Sci USA 101: 14228-14233, 2004.

20. Benchaouir R, Rameau P, Decraene C, Dreyfus P, Israeli D, Piétu G, Danos O and Garcia L: Evidence for a resident subset of cells with SP phenotype in the C2C12 myogenic line: A tool to explore muscle stem cell biology. Exp Cell Res 294: 254-268, 2004.

21. Ambudkar SV, Dey S, Hrycyna CA, Ramachandra M, Pastan I and Gottesman MM: Biochemical, cellular, and pharmacological aspects of the multidrug transporter. Annu Rev Pharmacol Toxicol 39: 361-398, 1999.

22. Yao J, Cai HH, Wei JS, An Y, Ji ZL, Lu ZP, Wu JL, Chen P, Jiang KR, Dai CC, et al: Side population in the pancreatic cancer cell lines SW1990 and CFPAC-1 is enriched with cancer stem-like cells. Oncol Rep 23: 1375-1382, 2010.

23. Zhang SN, Huang FT, Huang YJ, Zhong W and Yu Z: Characterization of a cancer stem cell-like side population derived from human pancreatic adenocarcinoma cells. Tumori 96: $985-992,2010$

24. Vohra J: Verapamil in cardiac arrhythmias: An overview. Clin Exp Pharmacol Physiol Suppl 6: 129-134, 1982.

25. Bellamy WT: P-glycoproteins and multidrug resistance. Annu Rev Pharmacol Toxicol 36: 161-183, 1996.

26. Broxterman HJ, Lankelma J and Pinedo HM: How to probe clinical tumour samples for P-glycoprotein and multidrug resistance-associated protein. Eur J Cancer 32A: 1024-1033, 1996.

27. Ince P, Appleton DR, Finney KJ, Sunter JP and Watson AJ: Verapamil increases the sensitivity of primary human colorectal carcinoma tissue to vincristine. Br J Cancer 53: 137-139, 1986.

28. Merry S, Fetherston CA, Kaye SB, Freshney RI and Plumb JA: Resistance of human glioma to adriamycin in vitro: The role of membrane transport and its circumvention with verapamil. Br J Cancer 53: 129-135, 1986.

29. Morrow M, Wait RB, Rosenthal RA and Gamelli RL: Verapamil enhances antitumor activity without increasing myeloid toxicity. Surgery 101: 63-68, 1987.

30. Tsuruo T, Iida H, Tsukagoshi S and Sakurai Y: Overcoming of vincristine resistance in P388 leukemia in vivo and in vitro through enhanced cytotoxicity of vincristine and vinblastine by verapamil. Cancer Res 41: 1967-1972, 1981.

31. Bruns CJ, Harbison MT, Kuniyasu H, Eue I and Fidler IJ: In vivo selection and characterization of metastatic variants from human pancreatic adenocarcinoma by using orthotopic implantation in nude mice. Neoplasia 1: 50-62, 1999.

32. Guillermet-Guibert J, Davenne L, Pchejetski D, Saint-Laurent N, Brizuela L, Guilbeau-Frugier C, Delisle MB, Cuvillier O, Susini $C$ and Bousquet $C$ : Targeting the sphingolipid metabolism to defeat pancreatic cancer cell resistance to the chemotherapeutic gemcitabine drug. Mol Cancer Ther 8: 809-820, 2009. 
33. Reddy KL, Zullo JM, Bertolino E and Singh H: Transcriptional repression mediated by repositioning of genes to the nuclear lamina. Nature 452: 243-247, 2008.

34. Georges E, Bradley G, Gariepy J and Ling V: Detection of P-glycoprotein isoforms by gene-specific monoclonal antibodies. Proc Natl Acad Sci USA 87: 152-156, 1990.

35. Al-Hajj M, Wicha MS, Benito-Hernandez A, Morrison SJ and Clarke MF: Prospective identification of tumorigenic breast cancer cells. Proc Natl Acad Sci USA 100: 3983-3988, 2003.

36. Dalerba P, Dylla SJ, Park IK, Liu R, Wang X, Cho RW, Hoey T, Gurney A, Huang EH, Simeone DM, et al: Phenotypic characterization of human colorectal cancer stem cells. Proc Natl Acad Sci USA 104: 10158-10163, 2007.

37. Clayton S and Mousa SA: Therapeutics formulated to target cancer stem cells: Is it in our future? Cancer Cell Int 11: 7, 2011.

38. Gibbs CP, Kukekov VG, Reith JD, Tchigrinova O, Suslov ON, Scott EW, Ghivizzani SC, Ignatova TN and Steindler DA: Stem-like cells in bone sarcomas: Implications for tumorigenesis. Neoplasia 7: 967-976, 2005.

39. Challen GA and Little MH: A side order of stem cells: The SP phenotype. Stem Cells 24: 3-12, 2006.

40. Wulf GG, Wang RY, Kuehnle I, Weidner D, Marini F, Brenner MK, Andreeff M and Goodell MA: A leukemic stem cell with intrinsic drug efflux capacity in acute myeloid leukemia. Blood 98: 1166-1173, 2001

41. Grichnik JM, Burch JA, Schulteis RD, Shan S, Liu J, Darrow TL, Vervaert CE and Seigler HF: Melanoma, a tumor based on a mutant stem cell? J Invest Dermatol 126: 142-153, 2006.

42. Szotek PP, Pieretti-Vanmarcke R, Masiakos PT, Dinulescu DM, Connolly D, Foster R, Dombkowski D, Preffer F, Maclaughlin DT and Donahoe PK: Ovarian cancer side population defines cells with stem cell-like characteristics and Mullerian inhibiting substance responsiveness. Proc Natl Acad Sci USA 103: 11154-11159, 2006.

43. Kondo T, Setoguchi T and Taga T: Persistence of a small subpopulation of cancer stem-like cells in the C6 glioma cell line. Proc Natl Acad Sci USA 101: 781-786, 2004.

44. Haraguchi N, Utsunomiya T, Inoue H, Tanaka F, Mimori K, Barnard GF and Mori M: Characterization of a side population of cancer cells from human gastrointestinal system. Stem Cells 24: 506-513, 2006

45. Asuthkar S, Stepanova V, Lebedeva T, Holterman AL, Estes N, Cines DB, Rao JS and Gondi CS: Multifunctional roles of urokinase plasminogen activator (uPA) in cancer stemness and chemoresistance of pancreatic cancer. Mol Biol Cell 24: 2620-2632, 2013.

46. Zhou J, Wang CY, Liu T, Wu B, Zhou F, Xiong JX, Wu HS, Tao J, Zhao G, Yang M, et al: Persistence of side population cells with high drug efflux capacity in pancreatic cancer. World J Gastroenterol 14: 925-930, 2008.

47. Kabashima A, Higuchi H, Takaishi H, Matsuzaki Y, Suzuki S, Izumiya M, Iizuka H, Sakai G, Hozawa S, Azuma T et al: Side population of pancreatic cancer cells predominates in TGF-betamediated epithelial to mesenchymal transition and invasion. Int $\mathrm{J}$ Cancer 124: 2771-2779, 2009.

48. Yang AD, Fan F, Camp ER, van Buren G, Liu W, Somcio R, Gray MJ, Cheng H, Hoff PM and Ellis LM: Chronic oxaliplatin resistance induces epithelial-to-mesenchymal transition in colorectal cancer cell lines. Clin Cancer Res 12: 4147-4153, 2006.
49. Okano M, Konno M, Kano Y, Kim H, Kawamoto K, Ohkuma M, Haraguchi N, Yokobori T, Mimori K, Yamamoto H, et al: Human colorectal $\mathrm{CD} 24^{+}$cancer stem cells are susceptible to epithelialmesenchymal transition. Int J Oncol 45: 575-580, 2014.

50. Zhao Y, Bao Q, Schwarz B, Zhao L, Mysliwietz J, Ellwart J, Renner A, Hirner H, Niess H, Camaj P, et al: Stem cell-like side populations in esophageal cancer: A source of chemotherapy resistance and metastases. Stem Cells Dev 23: 180-192, 2014.

51. Doyle L and Ross DD: Multidrug resistance mediated by the breast cancer resistance protein BCRP (ABCG2). Oncogene 22: 7340-7358, 2003.

52. Jensen RL, Lee YS, Guijrati M, Origitano TC, Wurster RD and Reichman OH: Inhibition of in vitro meningioma proliferation after growth factor stimulation by calcium channel antagonists: Part II - Additional growth factors, growth factor receptor immunohistochemistry, and intracellular calcium measurements. Neurosurgery 37: 937-946; discussion 946-937, 1995.

53. Zhao Y, Zhao L, Ischenko I, Bao Q, Schwarz B, Nieß H, Wang Y, Renner A, Mysliwietz J, Jauch KW, et al: Antisense inhibition of microRNA-21 and microRNA-221 in tumor-initiating stem-like cells modulates tumorigenesis, metastasis, and chemotherapy resistance in pancreatic cancer. Target Oncol 10: 535-548, 2015.

54. Jensen RL, Petr M and Wurster RD: Calcium channel antagonist effect on in vitro meningioma signal transduction pathways after grow th factor stimulation. Neurosurgery 46: 692-702; discussion 702-693, 2000.

55. Berridge MJ, Lipp P and Bootman MD: Signal transduction. The calcium entry pas de deux. Science 287: 1604-1605, 2000.

56. Hajnóczky G, Csordás G, Madesh M and Pacher P: Control of apoptosis by IP(3) and ryanodine receptor driven calcium signals. Cell Calcium 28: 349-363, 2000.

57. Cao QZ, Niu G and Tan HR: In vitro growth inhibition of human colonic tumor cells by Verapamil. World J Gastroenterol 11: 2255-2259, 2005

58. Trompier D, Chang XB, Barattin R, du Moulinet D'Hardemare A, Di Pietro A and Baubichon-Cortay H: Verapamil and its derivative trigger apoptosis through glutathione extrusion by multidrug resistance protein MRP1. Cancer Res 64: 4950-4956, 2004.

59. Ghibelli L, Coppola S, Rotilio G, Lafavia E, Maresca V and Ciriolo MR: Non-oxidative loss of glutathione in apoptosis via GSH extrusion. Biochem Biophys Res Commun 216: 313-320, 1995.

60. Wang F, Zhang D, Zhang Q, Chen Y, Zheng D, Hao L, Duan C, Jia L, Liu G and Liu Y: Synergistic effect of folate-mediated targeting and verapamil-mediated P-gp inhibition with paclitaxel-polymer micelles to overcome multi-drug resistance. Biomaterials 32: 9444-9456, 2011

61. Yalowich JC and Ross WE: Verapamil-induced augmentation of etoposide accumulation in L1210 cells in vitro. Cancer Res 45: 1651-1656, 1985.

62. Robinson BA, Clutterbuck RD, Millar JL and McElwain TJ: Verapamil potentiation of melphalan cytotoxicity and cellular uptake in murine fibrosarcoma and bone marrow. Br J Cancer 52: 813-822, 1985.

63. Spratlin J, Sangha R, Glubrecht D, Dabbagh L, Young JD, Dumontet C, Cass C, Lai R and Mackey JR: The absence of human equilibrative nucleoside transporter 1 is associated with reduced survival in patients with gemcitabine-treated pancreas adenocarcinoma. Clin Cancer Res 10: 6956-6961, 2004. 